\title{
Creo, luego existo e insisto: el arte elizamiano ante la ley
} I believe, then I Exist and Insist: the Elizamean Art Before the Law

\author{
María Giulianna Zambrano Murillo \\ Universidad San Francisco de Quito
}

\section{Resumen}

Este artículo interpreta la obra carcelaria del ex prisionero político independentista puertorriqueńo, Elizam Escobar (Ponce, 1948), como un acto de resistencia frente a la violencia de la ley imperial estadounidense y de la microfísica del poder disciplinario en prisión. En sus creaciones durante casi veinte años de encierro (1980-1999), el pintor ponceño propone un "arte de liberación", que recurre continuamente a la ambigüedad y a lo simbólico como forma de encarar la represión autorizada en la ley que procura mermar la subjetividad política del artista. Así, su obra es una invitación a mirar la prisión, la isla y la historia como espacios y discursos dominados por una injusticia continuamente amparada por la ley, gracias al diálogo crítico que establece con la misma en su pintura, en sus escritos y en su teoría del arte.

\section{Palabras claves}

Elizam Escobar / Derecho / Arte de liberación / Prisión / Puerto Rico / Independentismo.

\section{Summary}

This article interprets the work of the former political prisoner and Puerto Rican independence advocate, Elizam Escobar (Ponce, 1948), written in prison as an act of resistance in the face of the United States imperial legal violence and the microphysics of disciplinary power exerted in prison. During his almost twenty years of incarceration (1980-1999), the painter's creations proposed a "liberation art" that continuously recurs to ambiguity and symbolism as a way to confront the legalized repression that endeavored to impair the political subjectivity of the artist. Thus, his work is an invitation to view incarceration, the island, and history as spaces and discourses dominated by an injustice that is continually supported by law, thanks to the critical dialogue that he establishes with legality in his painting, his writing, and his art theory.

\section{Keywords}

Elizam Escobar / Law / Liberation Art / Prison / Puerto Rico / Independence Movement. 
El gran arte, como la vida, no se entiende nunca exhaustivamente o sin ambigüedad. Como la vida, es experimentado.

Elizam Escobar Los ensayos del artificiero

\section{Elizam Escobar frente a la ley}

En 1991 Elizam Escobar (Ponce, Puerto Rico, 1948) pinta su cuadro "La ficción" en la prisión de El Reno, Oklahoma. Han pasado once ańos desde su arresto en Illinois por formar parte de las Fuerzas Armadas de Liberación Nacional (FALN), grupo de militantes puertorriqueños pro independencia fuertemente reprimido por el gobierno estadounidense ${ }^{1}$. Mientras cumple una condena de 68 años, acusado de conspiración sediciosa y cargos relacionados, Escobar se pinta a sí mismo varias veces.

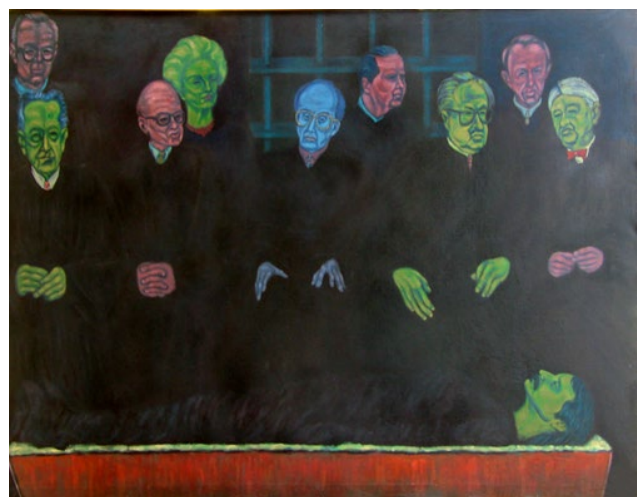

"La ficción" (1991a). Elizam Escobar

Acrílico sobre lienzo $(47$ x $72 \mathrm{~cm})$

En "La ficción" el artista yace inmóvil en un féretro frente a los miembros de la Corte Suprema de Justicia de la época que lo observan inquisitorialmente. Las rejas del fondo de la pintura hacen que todos estemos en la celda, suspendidos en ese escrutinio. Los jueces que han condenado a Escobar a la prisión todavía no están convencidos de la fuerza de la sentencia, de su letalidad. El cuadro nos interpela: ¿vive Elizam Escobar? ¿Viven aún el preso y su causa?

Escobar cuenta que cuando imaginó este cuadro tenía en mente la historia del conquistador Diego de Salcedo, un relato de cómo los taínos ahogaron al español para comprobar si de verdad era inmortal. Su pintura, nos dice, cuenta otra historia:

Ya no se trata de los oprimidos (los taínos) tratando de averiguar si los opresores (los españoles) son inmortales. En esta alegoría, la leyenda regresa, pero esta vez son los opresores

\footnotetext{
${ }^{1}$ Las FALN, activas entre 1960 y 1983, fueron uno de los grupos militantes por la causa independentista de Puerto Rico. El grupo, fundado por Filiberto Ojeda Ríos, las FALN estuvo más activo en Estados Unidos que en la isla, con una presencia fuerte en ciudades como Chicago y Nueva York. Varios de sus miembros fueron encarcelados y perseguidos por el FBI dentro de las actividades del programa de contrainsurgencia: COINTELPRO. (Ver Churchill y Wall [2002]). En 1980 Elizam Escobar fue arrestado junto a otros once compañeros en Illinois y acusado de conspiración sediciosa y otros cargos relacionados. Tras estar preso diecinueve años en diferentes prisiones de Estados Unidos fue, finalmente, indultado por Bill Clinton en 1999.
} 
(los jueces del imperio) cuestionándose si los oprimidos son o no son mortales; o, a otro nivel, cuestionándose la inmortalidad del arte y del artista: la ficción jurídica versus la ficción del arte (Escobar, 2013b, p. 18).

La puesta a prueba de la mortalidad del preso político en el cuadro, a diferencia del relato original, es una historia de supervivencia. El pintor ponceño sobrevive a los intentos del poder y de la ley imperial de terminar con su vida y con la de su causa al recluirlo. La posibilidad misma del cuadro es la prueba de esta existencia que, aun desde el gulag del imperio estadounidense, ofrece una respuesta: la ficción del arte.

En el caso de Escobar, el arte en forma de pintura, de escritura e, inclusive, de teoría se enfrenta a la ley al convocarla a un diálogo crítico en el que revela su ficcionalidad. Esta disputa que inicia en los juicios a los miembros de las FALN, juicios en los que Escobar y otros miembros del grupo pro independencia deciden no participar ${ }^{2}$, rechazando así ser sujetos jurídicos del imperio, se transporta a lo largo de su sentencia a los discursos e imágenes que produce el artista desde la prisión.

En este ensayo abordo esta relación entre pintura, teoría del arte, literatura y ley como un contrapunteo entre dos campos de fuerza, uno que reprime e intenta reducir las posibilidades de significación y acción la ley, y otro que expande los terrenos heurísticos ante esta represión el arte en relación con la situación colonial en Puerto Rico. La prisión como condena del sujeto jurídico en Escobar es asumida como proceso que busca la muerte del gesto político del sujeto colonizado frente al cual el gesto creativo de la pintura, la escritura y el pensamiento se ofrece como revelación de la vida de esta subjetividad política irreductible.

La prisión, estudiada en amplitud por Angela Davis como un complejo industrial, constituye una forma de desaparecer personas con la falsa esperanza de desaparecer los problemas sociales que representan $(2005$, p. 41). Tras la condena, el cuerpo encerrado del sujeto jurídico, el control de su tiempo-espacio, alimenta la ilusión de la supresión. Esto se debe a que, como sugiere Michel Foucault en Vigilar y castigar, la prisión tiene un doble fundamento. Por un lado, en una sociedad en que la libertad es un bien, la suspensión de esta libertad por la condena es de carácter jurídico-económico. Pero, por otra, la institución también tiene un fundamento técnico-disciplinario, al buscar una transformación del individuo mediante una microfísica del poder aplicada a la vida del preso con el fin de controlar su cuerpo y normalizar su conducta (2000, pp. 234-235).

Para Escobar, esta lógica era mucho más perversa en el contexto puertorriqueño. El tratamiento de prisioneros políticos como criminales comunes buscó reducir su acción política a actos delincuenciales, lo que implicaba, ante todo, la expulsión del militante anticolonial como sujeto político del horizonte de posibilidades para la isla, y su sometimiento a procesos disciplinarios de homogenización.

El artista, sin embargo, nos recuerda que queda la duda, la ambigüedad de esta ruptura. A través del acto de pintar, de la "ficción del arte", el pintor ponceño responde a la

\footnotetext{
${ }^{2}$ Los miembros de las FALN se declararon prisioneros de guerra, se rehusaron a participar en los juicios y, como sostiene Juan Carlos Rodríguez, "al rechazar la autoridad del sistema de justicia estadounidense, agregaron un nuevo elemento a la lucha anticolonialista: el surgimiento del militante anticolonialista como un sujeto político que rechaza el sistema legal del enemigo" (2011, p. 55) Esta y todas las traducciones al inglés son mías. De esta suerte, rechazan convertirse en sujetos jurídicos a la merced del sistema de justicia imperial que reduce sus actos políticos a actos criminales. La estrategia política de las FALN se alejó de la estrategia legalista del líder del Partido Nacionalista puertorriqueño, Pedro Albizu Campus, quien, en el primer momento de auge del nacionalismo en los años treinta, trató de promover la independencia de la isla explicando en términos legales la nulidad del Tratado de París que cedía la isla a Estados Unidos al fin de la Guerra Hispanoamericana en 1898.
} 
mirada vigilante del imperio con un "sigo aquî". El trazo elizamiano está en sintonía con lo que Eduardo Lalo llama "el deseo del lápiz" (2010) en el libro que lleva ese nombre. A partir de fotografías tomadas a las paredes y a los espacios de la penitenciaría sanjuanera, "Oso Blanco", deshabitada y a punto de demolerse, el autor medita sobre esta necesidad de la escritura-marca para el preso. Nos dice, "no tener el deseo del lápiz significa deshumanizarse o morir, [este deseo] es la pulsación de la vida que se manifiesta como un desbordamiento en el espacio reducidísimo (y, por ello, violentísimo de esta celda)" (Lalo, 2010, p. 14). El acto de escritura no implica únicamente la manifestación de libertad del preso, una marca "más-allá-de-la-ley" (p. 15), dentro de un sistema carcelario que pretende anularla por completo, también es una invitación a la lectura, a la observación y, ante esto, al reconocimiento de que el espacio carcelario nos pertenece a todos. De ahí que Lalo escriba en respuesta lo siguiente:

La celda, la cárcel, es el espacio que todos llevamos dentro. Ha estado oculto por el pudor, el miedo y la ignorancia, por el "bien pensar" de los lugares comunes y las débiles morales, por los proyectos de dominación política, las promesas del consumismo y el hábito de la libertad, por, en suma, una oportunista y terca ingenuidad. Sin embargo, pese a nuestros intentos higiénicos, cada uno de nosotros lleva en su interior el amplio catálogo de transgresiones de la humanidad (2010, p. 12).

Aun si los muros del presidio, los casos cerrados y las condenas intentan alejar este espacio contenido de lo social, no logran expulsar completamente las transgresiones que pretenden castigar. En esta "escritura-marca" la ficcionalidad de esta ilusión se revela. En el cuadro "La ficción”, Escobar nos lleva a la celda, nos vuelve cómplices en esta observación, mientras reafirma la existencia del sujeto político. Esto se verá en mayor detalle en los siguientes apartados que abordan su obra como un desafío recurrente que presiona los límites del terreno de lo que la ley y la microfísica del poder carcelario habilitan.

\section{El arte de liberación elizamiano frente a la visualidad de la ley imperial}

Nicholas Mirzoeff en "The Right to Look", siguiendo el argumento de Jacques Derrida sobre la ley, sostiene que desde el origen de la autoridad, el lugar de la ley no puede, por definición, sostenerse en nada que no sea ella misma (2011, p. 479). Es decir, la ley constituye una violencia sin base fundacional. De ahí que, continúa, "el supuesto origen de la autoridad en la legalidad sea, en realidad, en la fuerza [force], la imposición del cumplimiento de la ley [the enforcement of law]" (p. 480). Este proceso de autoautorización de la autoridad requirió un suplemento para volverse evidente, para justificar su fundación violenta y mística al igual que su continuidad; ese suplemento es lo que Mirzoeff llama "visualidad" (p. 480). La visualidad, que no se refiere únicamente a imágenes sino también a prácticas discursivas, clasifica, separa y estetiza, mientras retrata lo real y regula sus efectos materiales (p. 476).

La ley, en este sentido, perfila un campo de posibilidades. En el caso de la prisión $y$, específicamente, del presidio político, el concepto de la visualidad de la ley ofrece una potencialidad crítica al relacionarse con el estudio de su funcionamiento desarrollado por Foucault. A la norma jurídica que condena a la privación de la libertad por la criminalización del acto político disidente, le siguen una serie de prácticas de vigilancia y disciplinamiento que pretenden transformar la subjetividad del individuo condenado. En la prisión moderna, según el filósofo francés, el cuerpo del preso ha sido aumentado "con la individualidad del 'delincuente', la pequeña alma del criminal, que el aparato mismo del castigo ha fabricado como punto de aplicación del poder de castigar” (2000, p. 258). Esta combinación de privación de la libertad, vigilancia y disciplina normalizadora busca la homogenización que justifica horizontes de verdad sostenidos por la ley, por sus prácticas y por ese suplemento que Mirzoeff 
ha denominado visualidad. Es contra esta visualidad, con los discursos sobre sí mismo y las prácticas ejercidas sobre sí mismo, en tanto que sujeto jurídico condenado y delincuente, con las que Escobar dialoga para salvar su existencia como sujeto político disidente, al hacer de su cuerpo una ofrenda frente a una institución que intenta poseerlo y de su pensamiento la fluidez que escapa los esfuerzos disciplinarios. Esto, lo veremos en algunos ejemplo de su obra a continuación.

Primero, volvamos al cuadro "La ficción". Los jueces han determinado que Escobar es culpable, que su lugar es la cárcel, que la contienda política sobre el destino de Puerto Rico terminó, que sus reclamos son ilegítimos, y que el sujeto condenado ahora debe ser "normalizado" para expiar de su cuerpo el acto criminal. Así, autorizan la imposición continua del gobierno de Estados Unidos sobre el destino de la isla ${ }^{3}$. No obstante, cuando Escobar pinta, se autorretrata frente a ellos, defiende su derecho a mirar y, con él, su derecho a existir ante(s de) la ley. Ese derecho constituye un disenso frente a la visualidad de la ley del sistema político hegemónico y del sistema penitenciario, un reclamo del derecho a participar en la construcción de lo real (Mirzoeff, 2011). El gesto elizamiano es, de esta suerte, un desplazamiento de la frontera de la ley que lo encarcela, lo desautoriza, lo limita. En ese gesto, Escobar, como otredad colonial, como sujeto político, sigue existiendo y resiste la violencia normalizadora de la disciplina porque su cuadro es justamente resultado del acto que demuestra que aun vive, como sujeto y como causa colectiva.

"La ficción" no es el único ejemplo. En los años de encierro Escobar pinta, escribe, registra, archiva. Cada trazo, desde el garabato hasta la imagen elaborada en el lienzo, es una manera de responder a la violencia de la ley que intenta despojarlo de su subjetividad política y convertirlo, simplemente, en el prisionero \#88969-024. De ahí que a la mirada vigilante del Estado y al poder disciplinario en prisión que lo intentan reducir, el pintor y escritor ponceño responda recurrentemente con una ampliación del espacio de la celda que acusa la violencia del colonialismo estadounidense al igual que la violencia de cualquier ortodoxia política.

Por esto, la obra plástica, teórica y literaria de Escobar realizada en el encierro es vastísima y se construye desde la ambigüedad como resistencia a la disciplina despótica de la prisión. Desde su llegada a la cárcel, un sistema de prohibiciones hace que su proceso artístico gravite alrededor de la pregunta de qué se puede y no se puede hacer. En cada prisión, los medios de creación son diferentes y generan un proceso de educación individual independiente como resistencia (Escobar, 2013c). Consecuentemente, cuando no le permiten pintar escribe, cuando escribe teoriza y tiende los puentes necesarios para la comprensión de su obra total. Escobar se constituye así como uno de los mejores pensadores del encierro físico, pero también de la represión de las hostilidades de nuestro entorno y de la posibilidad liberadora del arte.

En 2013, el Museo de Arte de Puerto Rico (MAPR) en Santurce exhibió la muestra "Introspectiva Simbólica", inaugurada el 27 de agosto de ese año, donde se incluían varios cuadros pintados en prisiones estatales y federales de Estados Unidos como "La ficción". El curador del MAPR, Juan Carlos López, entiende la obra plástica del artista ponceño como un lienzo que "es un espacio abarrotado, claustrofóbico, en general sombrío. Sin embargo, no se trata de una pintura anecdótica; los personajes en su mayoría están ensimismados, no hay

\footnotetext{
${ }^{3}$ Vale la pena resaltar que la represión a las FALN no fue la única manifestación violenta del gobierno de Estados Unidos contra el nacionalismo e independentismo puertorriqueño. Desde el fin de la Guerra Hispanoamericana y, especialmente, a partir de la formación del Partido Nacionalista en 1922, las facciones pro independencia en la isla han sido continuamente perseguidas, sus líderes encarcelados e, inclusive, su proyecto político proscrito del sistema político como en los años de la Ley 53, conocida como ley de La Mordaza, que prohibió cualquier intento de cuestionar el gobierno estadounidense en la isla y que rigió durante la consolidación del Estado Libre Asociado en Puerto Rico.
} 
diálogo, no hay cruce de miradas, la escena está detenida, a la espera de nuestra mirada, la del espectador, para activarse" (López cit. en Escobar, 2013b, p. 7). La pintura de Escobar rehúye cualquier intento de limitar este horizonte de lo real y, en su lugar, enfrenta al espectador a un nuevo territorio de significación. Escobar nos invita a la celda, su celda, y la celda de aquella visualidad castrante que aparece como espectro en forma de rejas a lo largo de su obra.

En la misma línea de su pintura, Ensayos del artificiero (1999), una compilación de reflexiones teóricas sobre arte escritas entre 1983 y 1993, es resultado de estos años, de este proceso. En el libro se manifiesta la intención del artista ponceño de defender el arte no como testimonio, sino como un intercambio que va más allá del código lingüístico e ideológico y que permite la explosión de los límites de significación. Esta idea se transmite a una obra plástica en la que abundan los autorretratos donde el artista hace de su propio cuerpo, que el Estado intenta poseer al encarcelarlo, una ofrenda a la heurística del arte, y argumenta:

Mi cuerpo, como obra de arte, como "cuerpo exhibido", como una heurística, no me pertenece. Es otro. El cuerpo hace una ofrenda, un intercambio simbólico. Este intercambio simbólico es lo que yo opongo al ideologismo (la reducción de todo a la ideología) que viene desde afuera a codificar la experiencia y el conocimiento de mi cuerpo. Mi cuerpo expuesto contiene poéticamente todo eso que la ideología dominante quiere domesticar o reducir al placer fácil y barato, el placer que hace del cuerpo un objeto dislocado de toda libertad. En esta libertad, en esta responsabilidad, y en el acto voluntario de ofrenda, el cuerpo exhibido se hace sublime (se transfigura) para contener todas las posibilidades que hacen del cuerpo (dolido, redimido, "triunfante") la imagen rescatadora de lo que de otra forma se hará parte del olvido colectivo e histórico, o de la documentación cuantitativa, nominal, y arbitraria (1999, p. 212).

Aunque el cuerpo se encuentre encerrado, en la exposición del mismo en la pintura se abre un territorio de reflexión nuevo y se resiste el intento de la disciplina carcelaria de domesticarlo. En este sentido, la libertad se ejerce en la generación de este intercambio simbólico que, ante todo, pretende resistir el olvido o la "verdad" del régimen discursivo hegemónico e interpelar al interlocutor para formar parte activa de este proceso heurístico liberador.

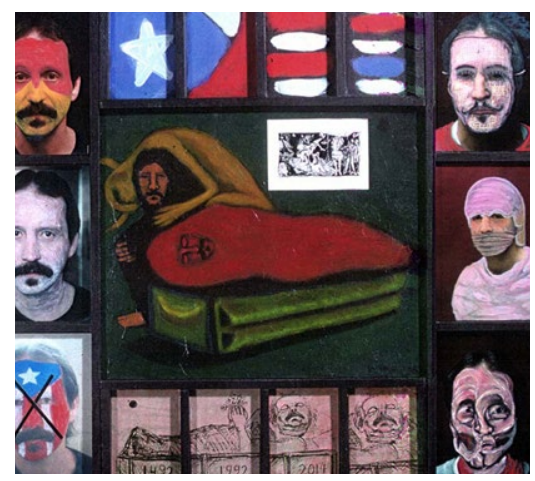

"Heurística \#1" (1992). Elizam Escobar Acrílico, fotografía y collage sobre masonite $(16 \times 18 \mathrm{~cm})$

Por ejemplo, en el cuadro "Heurística \#1", una mezcla de pintura, fotografía y collage, Escobar se retrata a sí mismo diez veces, explorando diferentes componentes de su propia subjetividad. 
El pintor aparece amordazado, desfigurado, con su identidad puertorriqueńa tachada. Aparece también su cuerpo muerto en un ataúd marcado por fechas, otra vez en un sarcófago acompañado de su doble velándolo, mientras el doble carga al vejigante de tantas remembranzas de la isla muerto a sus espaldas. Sus múltiples rostros parecen tener como título una bandera puertorriqueña tras las rejas. Aquí Escobar ofrece su cuerpo, sometido a prácticas disciplinarias que lo constrińen o lo niegan, ejemplificadas en la mordaza, el tachón, la muerte. Pero, el cuerpo es múltiple y rehúye cualquier lectura unívoca de esta ofrenda; así, se redime. Esa es la heurística del arte elizamiano, constante ejercicio de indagación y revelación. Esta posibilidad del arte es una parte fundamental para el proceso de liberación que defiende y para su compromiso ético con las exigencias de la lucha política.

La "política del arte", según sostiene, "tiene sus propias formas de afectar al mundo y lo político-directo, siempre que el poder de la imaginación pueda crear una relación simbólica entre los participantes, la obra de arte, y el mundo concreto" (1999, p. 97). A diferencia del arte político-directo, que pretende dirigir, prescribir o controlar la realidad social, similar a lo Mirzoeff denomina "visualidad", el arte de liberación que teoriza Escobar desde la prisión no niega la ambivalencia del intercambio, la reciprocidad o el antagonismo entre los interlocutores, les permite ver y así participar en la construcción de lo real. En su lienzo, en las páginas de sus escritos, la lucha política no ha concluido. De esta suerte, el "artista político de la liberación" no sólo disfruta de la "irrealidad" del arte que lo impulsa a la libertad, aquella ficción, sino que sabe que esta libertad es paradójica y requiere una constante puesta a prueba.

El libro Antidiario de prisión: el beso del pensamiento (2013) es otra manifestación de este propósito de sobrevivir el confinamiento, pero desde la fluidez de su pensamiento: un texto de 389 páginas escritas entre 1988-1995, conservando en la versión publicada la imagen de la página original, la caligrafía de Escobar, el tachón, el bosquejo, el dibujo. Justamente, cuando se le prohíbe pintar en la prisión de Oklahoma, Escobar empieza a dirigir la pulsión de su lápiz a la escritura. Este libro emerge como un intento de "develar el pensamiento de forma espontánea, pero a través de una estructura cronológica” (2013a, p.1). El ejercicio sostenido de captar su flujo de conciencia vuelve al antidiario un documento único que es, a la vez, un testimonio, un diario teórico, un diario onírico, una bitácora, un cuaderno de bocetos, una colección de citas de estudio, una sucesión diálogos y monólogos internos. En este proceso, el momento esperado es el beso, aquel encuentro de pensamiento y lenguaje donde se logra "el acontecimiento del ser" (2013a, p. 42). Ese es el beso que resiste las fuerzas aniquilantes de la mirada de ley y de la disciplina carcelaria. Ese beso al que la sanción normalizadora de la prisión no llega.

En sintonía con sus elaboraciones teóricas, el antidiario es otra forma en la que el arte, en este caso la escritura, permite "la realización imaginaria de necesidades insatisfechas y la explosión de contradicciones", siendo el único lugar donde "es posible inventar una verdad a pesar de todas las fuerzas hostiles de la vida de prisión" (1999, p. 205). La verdad elizamiana es esta constante puesta a prueba de su propio pensamiento, de su libertad y de su soledad en confinamiento. Las páginas caligrafiadas son una muestra más de la supervivencia de aquella subjetividad política acechada por el encierro. El ejercicio, nuevamente, desplaza las barreras carcelarias, mientras acerca al lector a este espacio, que aun siendo celda, se transfigura en una zona autónoma de liberación de significados y de interpretaciones más allá de la ley.

La propuesta estética elizamiana de ofrecer su cuerpo y su pensamiento al ejercicio del arte responde al rescate de esta subjetividad política, que peligra en las condiciones de encierro y se vuelve así una propuesta política colectiva. Nos dice:

mi martirio, mi santidad, mi celibato obligado, mi dolor, mi sufrimiento, devienen en la imagen exhibida del cuerpo individual y colectivo. Es en este sentido que puedo decir que lo 
personal es político. Es en este sentido que la vergüenza de ser un objeto de exhibición me redime como un acto de liberación (1999, p. 211; énfasis en el original).

Pero no es sólo una liberación frente al encierro, la ofrenda recurrente de su cuerpo y de la intimidad de su pensamiento, la politización de lo personal se enfrentan también a otras formas que pretenden reducirlo, como el colonialismo y la disciplina que niegan la disidencia. Así, el ejercicio de liberación es múltiple y recurrente.

\section{La insistencia en la justicia del gesto elizamiano}

En su cuadro "La máquina del tiempo" (1993), pintado en la prisión de El Reno, Oklahoma, Escobar una vez más se retrata a sí mismo, pedaleando una bicicleta, vistiendo ropas deshechas con hilos sueltos suspendidos que le dan movimiento a la imagen. Su cuerpo tiene una soga enredada al cuello, una soga que ha sido cortada, una soga que no lo ata a ningún sitio pero que sugiere que en algún momento estuvo a punto de morir en la horca. La mirada de Escobar en el cuadro se dirige hacia atrás; es una mirada sosegada, casi melancólica, que no refleja paranoia alguna, sino una suerte de ansiedad suscitada por algo que se abandona. Este cuadro está inspirado en la pintura de Francis Bacon, Retrato de George Dyer en bicicleta de 1966. A diferencia de la obra del pintor británico, donde las ruedas de la bicicleta y el rostro de Dyer parecen moverse en todas las direcciones con trazos que privilegian el movimiento, en el cuadro de Escobar la dirección es clara. La bicicleta sigue su marcha ecuánime hacia adelante, aún si el rostro mira hacia atrás.

Cuando vi por primera vez esta pintura en la "Introspectiva simbólica" de Escobar dos bocetos acompañaban la imagen. En ellos, la bicicleta en la que se escapa el pintor es una estática, retenida al suelo. Este elemento desaparece en la pintura final, donde el ciclista parece volar sobre un astro. Varias preguntas surgieron mientras contemplaba la imagen: ¿qué emoción, energía o pensamiento habría llevado a Escobar a decidir que la bicicleta no sería estática en la pintura final? ¿Por qué en el autorretrato el pintor puertorriqueño mira hacia atrás? ¿Qué es lo que existe en ese espacio fuera del marco de la pintura, al que la mirada del ciclista se dirige? Si el marco de una pintura, como sugiere Derrida en The Truth in Painting, "presiona el límite mismo e interviene en el adentro sólo en la medida en que el adentro tiene una carencia, le falta algo, algo de sí mismo" (1987, p. 56), ¿qué es lo que le hace falta al interior de esta escena para liberar la fuerza de su significado?

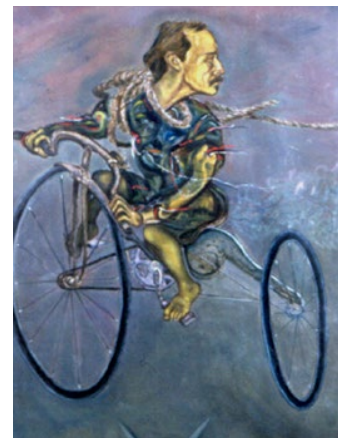

"La máquina del tiempo". Elizam Escobar

Óleo sobre lienzo sintético $(68 \times 48 \mathrm{~cm})$

El tropo del vuelo es un lugar común en la literatura y arte carcelarios como imagen liberadora al igual que como motivo onírico de importancia. Ante los mecanismos disciplinarios 
de apropiación del cuerpo y del presente, el sujeto prisionero que intenta reafirmar su humanidad en el encierro se presenta a sí mismo como dueño de su mente, de su espíritu. En donde el cuerpo está encerrado, la imaginación libera; la creación de imágenes escapistas, liberadoras o teletransportadoras proliferan buscando autonomía, una realidad virtual que transponga la materialidad. No es sorpresa, entonces, que Escobar decida en un momento dado que la imagen lo lleve a ese más allá hacia el cual el cuerpo no puede despegar todavía.

Pero, ¿por qué mira atrás? Si la mirada no muestra el miedo de la persecución, sino una cierta melancolía, ¿no será aquella mirada la misma que Walter Benjamin encuentra en el ángel de la historia que contempla las ruinas del pasado $(2008 \text {, p. } 69)^{4}$ ? ¿ No será la bicicleta la máquina del tiempo que comanda el impulso hacia adelante, aquella fuerza que lo lleva hacia el futuro, pero frente a la cual la mirada del artista ponceńo nos recuerda que pensar en el pasado es urgente, que mirar hacia atrás es necesario? Sin embargo, a veces, al mirar el cuadro, ¿no parece acaso que Elizam está a punto de cambiar el curso de la bicicleta de regreso a lo que mira que es, a fin de cuentas, la prisión?

Una vez más el gesto elizamiano recurre a la ambigüedad. La huida, aun si la imagen es liberadora, es imposible. Para Escobar, volver la mirada insistente al espacio carcelario es imperativo. Descubrir la fisura que permita ver que la prisión es la epítome de un sistema de injusticia es lo que atrae esa mirada insistente y que invita al interlocutor a intensificarla. Esta es la única posibilidad para la justicia, como sugiere Giorgio Agamben en Lo que queda de Auschwitz (2014). Para el filósofo italiano uno de los equívocos más comunes al aproximarse a la violencia de lugares como el campo de concentración es confundir categorías éticas con categorías jurídicas. De ahí que sea importante, continúa, reconocer que el derecho "tiende exclusivamente a la celebración del juicio, con independencia de la verdad o de la justicia" (2014, pp.17-18). Existe un vicio de conciliación, una necesidad de cierre, de sentencia, que no logra hablar de ese Auschwitz que sigue existiendo. A partir del estudio de la obra de Primo Levi, a quien considera el testigo perfecto por su insistencia inagotable en hablar y escribir de Auschwitz, Agamben reflexiona acerca de un nuevo elemento ético denominado "zona gris [...] una gris e incesante alquimia en la que el bien y el mal y, junto a ellos, todos los metales de la ética tradicional alcanzan su punto de fusión" (2014, p. 20). Esta zona gris habita un "más acá", es nuestro primer círculo para comprender que toda insistencia en la justicia es un reconocimiento de la imposibilidad de que existan para ciertos horrores una responsabilidad asumible, una culpa atribuible, un castigo equiparable a los daños. En esta zona gris, una zona de irresponsabilidad, mas no de impunidad, el testimonio obstinado emerge como una necesidad de justicia que reconoce que su lenguaje está lleno de lagunas, de mutilaciones; pero, sabe que estas imposibilidades revelan aquello que es indecible, único punto de partida.

Ahí donde se celebró la ficción jurídica, Escobar responde con la insistencia en repensar el espacio carcelario, no deshabitarlo, no dejarlo del todo. Finalmente, la prisión y su violencia se transforman en esa "zona gris" a la que hay que convocar a la discusión de la historia. No es coincidencia que, por este motivo, en gran parte del arte carcelario la historia sea uno de los epicentros reflexivos. Como sugiere Ioan Davies en Writers in Prison, un trabajo central en el estudio de la literatura de confinamiento, "cada pizca de escritura o canto carcelarios no es sólo una manera de pensar en lo que se hizo, o en las consecuencias futuras de acciones pasadas, sino un reconocimiento de que el texto [....] se vuelve un proyectil hacia un futuro resultante de otras historias" (1990, p. 231).

En el caso de Escobar, Davies nos diría que las marcas en las paredes de la prisión, los trazos en los lienzos, los flujos de pensamiento en las páginas del antidiario, las reflexiones

\footnotetext{
${ }^{4}$ Ver la tesis IX de "Tesis de la filosofía de la historia".
} 
teóricas del artificiero habitan las fisuras entre los adoquines sobre los cuales una maquinaria violenta continúa retumbando (1990, p. 230). Desde esta fisura, una forma de repensar la historia emerge a través de un arte que es a la vez individual, autorreflexivo y colectivo. De ahí que Escobar piense en el "arte de liberación" como aquel que "surge desde las zonas reprimidas de una humanidad que se inventa y reinventa contra todas las epistemologías que pretenden ser representativas de esa misma humanidad" (1999, p. 82). Bajo el colonialismo estadounidense, este gesto creativo aparece como un mecanismo para, por una parte, enfrentar una legitimidad que lo anula como sujeto político y, por otra, repensar la propia necesidad estética y política del colonizado.

La obra de Escobar demuestra que la función del arte es lidiar con la ausencia en las construcciones discursivas de la visualidad, presionar sobre los horizontes de lo posible y de lo real defendiendo nuestro "derecho a mirar" (Mirzoeff, 2011). En este sentido el arte de Escobar se vuelve una invitación a la reflexión crítica frente a la represión inherente en aquello que nos es dado como real, su material es el cuestionamiento de los procesos de significación. Este ejercicio está, sin duda, en sintonía con otras iniciativas que, desde afuera, intentan llamar la atención a la problemática del presidio político de puertorriqueños. Por ejemplo, en 1998 el artista puertorriqueńo Antonio Martorell inauguró una instalación llamada "Como Unión". En ella Martorell "traía a la mesa" a los quince presos políticos puertorriqueños en cárceles en Estados Unidos. Su intención era, justamente, visibilizar esa ausencia de la discusión del presidio y, por extensión, de la causa independentista en el discurso político en la isla.

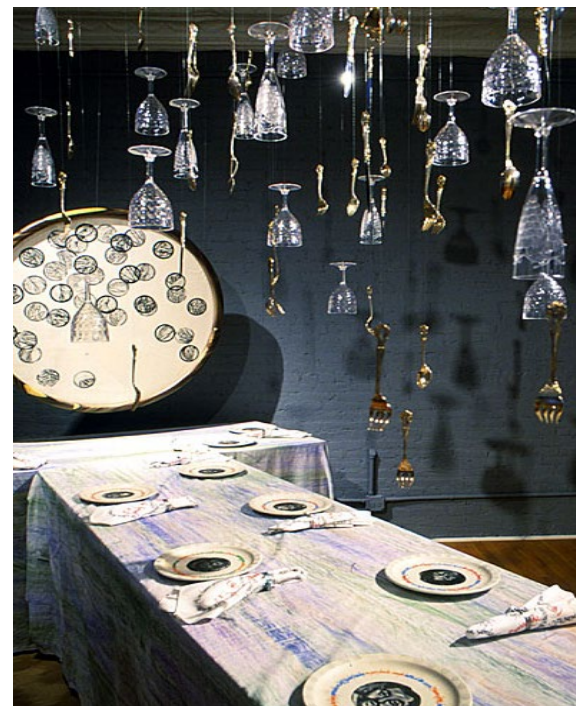

"Como Unión". Antonio Martorell

Fotografía del Archivo Documental A. Martorell

En la instalación, los visitantes eran invitados a una experiencia de esta ausencia que revela. Primero, tenían que pasar por una alfombra de color rojo sangre en la que estaban escritas las sentencias de los quince prisioneros. Después, se encontraban con una ducha gigante, como al acecho, con lupas que magnificaban partes de cuerpo. Al final, aparecía una mesa con quince puestos vacíos. En la mesa, había sólo servilletas y platos con los nombres y rostros de los ausentes. Dejando a un lado lo opresivo de las otras partes de la instalación, la última sala constituye una especie de santuario: finalmente, este escenario de comunión. En 
esta comunión, Escobar existe e insiste de la misma manera que lo hace en cada uno de los elementos que componen su obra carcelaria. La mesa de Martorell les devuelve a los ausentes la capacidad de participar en esta construcción de lo real y de los horizontes posibles de la isla. Asimismo, a los espectadores los invita a mirar, a aceptar aquel derecho a mirar, aquello que la prisión esconde.

Lo que en Martorell es una invitación a reconocer la ausencia de una discusión del presidio político, en el arte de Escobar se vuelve una amplificación de lo que sabemos de este proceso y presiona sobre aquella visualidad de lo real que la ley y la historia oficial construyen. Desde el rescate de su subjetividad política a través de la creación, la obra de Escobar sigue siendo denuncia y disidencia dentro del corazón de la maquinaria represiva colonialista: sus prisiones constituyen "esa región sombría en el aparato de justicia [...] el lugar donde el poder de castigar [...] ya no se atreve a actuar a rostro descubierto" (Foucault, 2000, p. 259).

Quisiera cerrar este artículo con un cuadro que demuestra, una vez más, esta afrenta del gesto creativo de Escobar y la insistencia en la justicia. En el cuadro "El ahorcado", pintado en 1991 en la prisión del El Reno, Oklahoma, el autor ponceńo ofrece de nuevo su cuerpo al ejercicio de la significación desde la ambigüedad. En él, el artista aparece ahorcado y semicubierto por una especie de capullo en forma de pez que empieza a absorberlo y que invisibiliza la mitad de su cuerpo. El ahorcamiento como práctica suicida es puesto en duda porque sus manos aparecen atadas. ¿Quién es culpable de esa muerte? La pregunta, en este caso, tiene una función doble. Por un lado, denuncia a la ley que reduce al sujeto político y lo somete a su aniquilación en la institución penitenciaria. Por otro, es un llamado a la justicia, a la discusión de la responsabilidad de ese acto violento. Así, insiste en esa zona gris y, en ese salto a lo colectivo del arte elizamiano que se construye desde lo personal, nos lleva a pensar en la violencia colonial en la historia puertorriqueńa, en la isla asfixiada y atada por el discurso jurídico del colonialismo.

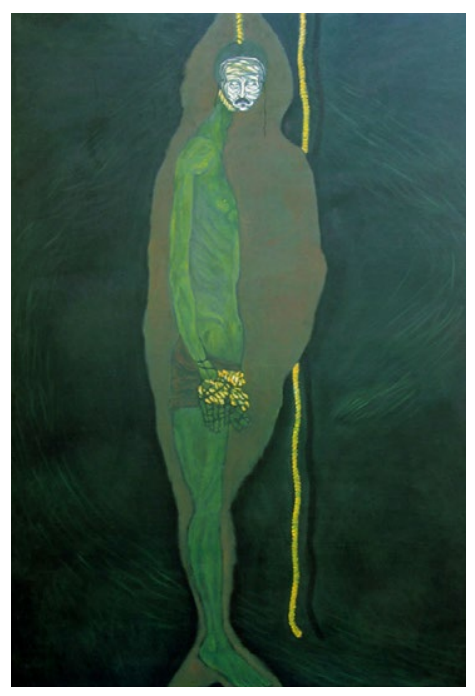

"El ahorcado" (1991b). Elizam Escobar Acrílico sobre lienzo $(78 \times 48 \mathrm{~cm})$ 


\section{Referencias bibliográficas}

Agamben, G. (2014). Lo que queda de Auschwitz. Valencia: Pre-Textos.

Benjamin, W. (2008). Ensayos escogidos. México: Ediciones Coyoacán.

Churchill, W. y Vander J (2002). Wall Agents of Repression: The FBI's Secret Wars Against the Black Panther Party. Cambridge: South End Press.

Davies, I. (1990). Writers in Prison. Toronto: Between the lines.

Davis, A. (2005). Abolition Democracy. Beyond Empire, Prisons, and Torture. Toronto: Seven Stories.

Derrida, J. (1987). The Truth in Painting. Chicago: University of Chicago Press.

Escobar, E. (2013a). Antidiario de prisión: el beso del pensamiento. Río Piedras: Qease.

- (2013b) Elizam Escobar. Introspectiva simbólica. Santurce: Museo de Arte de Puerto Rico.

- (2013c). Entrevista personal. San Juan, Puerto Rico.

- (2006). Cuadernos de cárcel. San Juan: Editorial del Instituto de Cultura.

- (1999). Los ensayos del artificiero. Cayey: Editorial Sopa de Letras.

Foucault, M. (2000). Vigilar y castigar. Madrid: Siglo XXI Editores.

Lalo, E. (2010). El deseo del lápiz: castigo, urbanismo, escritura. San Juan: Editorial Tal Cual.

Mirzoeff, N. (2001). The Right to Look. Critical Inquiry, 37 (3), 473-496.

Rodríguez, J. (2011) The Figure of the Enemy in Elizam Escobar's "La Ficcion". Journal of Latin American Cultural Studies, 20 (1), 49-61. DOI: http://dx.doi.org/10.1080/13569325. 2011.562633

\section{Imágenes}

Escobar, E. (1993). La máquina del tiempo. Óleo sobre lienzo sintético, 68 x $48 \mathrm{~cm}$.

Colección del artista.

- (1992). Heurística \#1. Acrílico, fotografía y collage sobre masonite, 16 x $18 \mathrm{~cm}$. Colección del Dr. Ángel Collado Schwarz.

- (1991a). La ficción. Acrílico sobre lienzo. 47 x 72 . Colección del artista.

- (1991b). El ahorcado. Acrílico sobre lienzo. 78 x 48. Colección del autor.

Martorell, A. (1988). “Como Unión”. Fotografía del Archivo Documental A. Martorell. 


\title{
Poéticas sobre la justicia en el modernismo mexicano. Manuel Gutiérrez Nájera y Salvador Díaz Mirón \\ Poetics on Justice in Mexican Modernism. \\ Manuel Gutiérrez Nájera and Salvador Díaz Mirón
}

\author{
MANuel de J. JimÉnez Moreno \\ Universidad Nacional Autónoma de México
}

\section{Resumen}

El siguiente artículo indaga las concepciones sobre la justicia de dos poetas modernistas mexicanos: Manuel Gutiérrez Nájera y Salvador Díaz Mirón. A partir de la intersección derecho en la literatura, explora las relaciones entre poesía y justicia en estos autores esenciales de la tradición mexicana y continental. En un primer momento, se reflexiona en torno a la importancia del movimiento modernista como proyecto estético y político, marcando sus repercusiones en América Latina como una epistemología singular. Posteriormente, se aborda el estudio de los poetas considerando no sólo las piezas literarias, sino aspectos biográficos y textos prosísticos que dejan ver su visión sobre la ley, las libertades básicas y la justicia.

\section{Palabras claves}

Poesía modernista / Sentido de justicia / Manuel Gutiérrez Nájera / Salvador Díaz Mirón / Derecho en la literatura.

\section{Summary}

This article looks into the meaning of justice in the work of two Mexican modernist poets: Manuel Gutiérrez Nájera and Salvador Díaz Mirón. Considering the intersection of Law in Literature, this article explores the relation between poetry and justice developed by these two authors, the works of whom are fundamental not only in Mexico but in the rest of Latin America as well. The first part of the article reflects on the importance of the modernist movement as an aesthetic and political project to highlight its impact on Latin America as a singular epistemology. The second part aims at studying these poets' literary pieces, as well as the biographical aspects and texts written in prose that reveal their vision about the law, basic freedoms and justice.

\section{Keywords}

Modernist Poetry / Conceptions of Justice / Manuel Gutiérrez Nájera / Salvador Díaz Mirón / Law in Literature.

\section{Introducción: La justicia y el movimiento Derecho y Literatura latinoamericano}

Son varios los esfuerzos por establecer una tradición genuina de Derecho y Literatura en Latinoamérica. Actualmente existen autores y académicos considerando esta área de oportunidad en los estudios interdisciplinarios entre ciencias sociales y humanidades. Son varias ramas jurídicas (penal, constitucional, civil, laboral, etc.) las que se pueden enlazarse satisfactoriamente con la obra literaria apelando a contenidos e imaginarios, para así robustecer la intersección "derecho en la literatura”. El tema de la justicia, propio de la filosofía práctica, es uno de los

\footnotetext{
${ }^{1}$ Profesor de la Facultad de Derecho de la UNAM. Coordinador del curso "Derecho y Literatura". Contacto: mjimenezm2@derecho.unam.mx
} 
tópicos esenciales en la formación de los Estados latinoamericanos si consideramos su origen ilustrado y los antecedentes coloniales que invariablemente los hermana. Por esta razón, en las siguientes líneas se desarrolla un esfuerzo intelectual que intenta unir la justicia con la literatura, particularmente, con la poesía modernista.

Se usa en este trabajo la voz "poética" no en un sentido formal, sino en un sentido particular, es decir, como el acto creativo por el cual los poetas se apropian del fenómeno poético y lo redireccionan hacia una temática particular, que en este caso será la de la justicia. Para ello, partiremos con el análisis de la confluencia entre el modernismo como movimiento artístico y las concepciones liberal y social de la justicia en Latinoamérica, todo esto atendiendo al contexto mexicano y utilizando únicamente los ejemplos de Manuel Gutiérrez Nájera y Salvador Díaz Mirón. Aunque es cierto que el problema de la justicia no juega un papel clave para estos poetas o, por lo menos, no se ha evidenciado lo suficiente este asunto desde la crítica literaria, sí se puede rastrear una posición particular reflejada en unos cuantos poemas que son susceptibles de ser leídos a la luz del derecho y la ética.

\section{El modernismo y la justicia}

Uno de los movimientos intelectuales más significativos en América Latina es el modernismo. En literatura, hasta la aparición del modernismo se pudo revertir, en cierta proporción, los procesos colonizadores que desde el Siglo de Oro fijaron las tendencias culturales y artísticas para los dominios americanos. A pesar del influjo de los poetas franceses, el modernismo terminó operando como una corriente emancipadora, ya que permitió mostrar una América Latina cosmopolita, con valores locales tendientes hacia el universalismo, y en diálogo franco con los discursos científicos y filosóficos de finales del siglo XIX. Para Octavio Paz,

Las creencias de Darío y de la mayoría de los poetas modernistas son, más que creencias, búsqueda de una creencia y se despliega frente a un paisaje devastado por la razón crítica y el positivismo. En ese contexto, el paganismo no sólo designa a la Antigüedad grecorromana y a sus ruinas sino a un paganismo vivo: por una parte el cuerpo y, por otra, a la naturaleza (1997, p. 415).

Para el poeta mexicano, el modernismo se opone tanto al materialismo positivista como al espiritualismo cristiano ${ }^{2}$. En ese momento, la sociedad decimonónica mexicana se encontraba tensada entre estas dos fuerzas ideológicas. Por una parte, el grupo de "Los científicos", afines al gobierno porfirista, impulsaban las ideas de Augusto Comte y otros autores europeos para modernizar la nación. Por otra parte, los círculos conservadores y clericales reafirmaban la doctrina católica como eje civilizatorio para superar la "crisis" de valores en el país. Este escenario, si bien con sus variaciones y peculiaridades, se repetía en varias naciones latinoamericanas. El

\footnotetext{
${ }_{2}^{2}$ Para Juan Ramón Jiménez, poeta que conoció ampliamente el modernismo, éste no iniciaba en América ni oponía espiritualidad y materialismo: "Repito que el modernismo, el movimiento modernista, empezó en Alemania a mediados del siglo XIX y se acentuó mucho a fines del siglo XIX. Fue muy importante entre los teólogos que empezaron ese movimiento. La idea era unir los dogmas católicos con los movimientos científicos modernos" (Jiménez, 1999, p. 74). Así, para el poeta español, a Unamuno se le decía, mucho antes de que llegara Darío a Madrid, "ese tío modernista" y, por tanto, era un error que se le considerara a Darío el iniciador del modernismo: "El error está en que generalmente los poetas no son teólogos y toman el nombre más bien de Rubén Darío y aceptan lo que en Rubén Darío se llama modernismo, más que en Unamuno, porque no están enterados tanto del movimiento alemán teológico como del modernismo francés literario. Pero lo curioso es que en Francia, de donde viene a Hispanoamérica y a España una parte considerable del modernismo, en Francia, no se llama modernismo. Es decir: en Francia se llama modernismo al teológico pero no al literario. El literario se llama parnasianismo, simbolismo, impresionismo" (p. 187).
} 
modernismo, siguiendo con las ideas de Octavio Paz, inicia con un propósito formal "una búsqueda del ritmo verbal”, para consagrar una visión del universo como cadencia cósmica. Sin embargo, ese ritmo a veces contenía pausas e irregularidades. El ritmo del modernismo no fue melódico en todos sus compases. En el afán de contrarrestar cualquier sistema de creencias hegemónico, el temperamento modernista se afianza en la contemplación de lo fragmentario y probablemente en la sublimación de las piezas bellas, perfectas y efímeras.

De este modo, "el arte moderno se sabe mortal y en eso consiste su modernidad. El modernismo llega a ser moderno cuando tiene conciencia de su mortalidad, es decir, cuando no se toma en serio, inyecta una dosis de prosa en verso y hace poesía con la crítica de la poesía" (Paz, 1997, p. 416). Darío y sus seguidores mezclan los géneros y enarbolan un arte ecléctico, donde no sólo prosa y verso se confunden, sino que el arte y la ciencia también tocan sus extremos. La originalidad de los modernistas, nos dice Paz, está en una apropiación de la lengua y sus ritmos y, sobre todo, en ser una visión analógica heredada de los románticos y los simbolistas.

El proyecto modernista, verdaderamente panhispánico, se mueve como un bloque intelectual. Existe un sentido profundo por renovar las formas poéticas, darle nuevos bríos al verso clásico e incluso regresar hasta los albores del español para recuperar otras tradiciones poéticas ${ }^{3}$. En la praxis, el modernismo es una actitud concreta: llevar a sus últimas posibilidades la plasticidad del lenguaje, incluso a costa de desoír la realidad. "Esta generación hispanoamericana, en efecto, se autodefinió como una familia continental, una estirpe del mismo linaje, un grupo literario con afinidades, una genealogía común y compartida; una fraternidad donde la sensibilidad, las esencias y el proyecto los une" (Díaz Ruiz, 2007, p. 27). En efecto, se trata de una colectividad distinta, consagrada para alcanzar una expresión innovadora que sea disidente del pasado inmediato peninsular, pero conciliador con el pasado remoto y los puentes del español con otras lenguas. El puente, dicho sea de paso, se extiende con el francés.

Cuando el poeta modernista se inicia en esta cofradía secularizada, se le exige un dominio universal de la cultura y conocimiento palpable de otras lenguas. Se trata de un movimiento aristocrático, de personas que pueden acceder a las altas esferas de la cultura y cuya preocupación es eminentemente estética. Esto resulta paradójico con la historia de su líder, Rubén Darío, quien aunque no arribando de la pobreza, realiza sacrificios y vive penurias para salvar el proyecto estético, que para ese entonces, se convertía más en un proyecto ético. Entonces el modernista no se preocupa por apalear los males de las sociedades de su tiempo, ni toma la espada de la poesía social ${ }^{4}$; todo lo contrario, busca edificar "otra" sociedad, una república de letras que se cimienta en una cultura primordialmente libresca. El modernista

\footnotetext{
3 "El proyecto estético del modernismo concibió y manifestó también una doble voluntad de integración; por una parte, mediante el cosmopolitismo o universalismo se delineó un carácter universal de inspiración y temática tanto europeísta como orientalista; por otra, se planteó una articulación continental, hispanoamericana, que auspició y fraguó una cohesión artística y generacional; el escritor modernista consolidó así una comunicación y correspondencia con los más relevantes escritores de nuestra América. Ambas facetas sirvieron para constatar una esencia moderna: hispanoamericano por ser integrante de una cultura y una sociedad con rasgos comunes y semejantes; y, por efecto del redimensionamiento del mundo y de nuevas formas de comunicación, universal" (Díaz Ruiz, 2007, p. 61).

${ }^{4}$ La idea de poesía social no sólo fue vista con aversión por el modernismo, sino también por la poesía pura, que fue en mucho una reacción al movimiento. "[Después del romanticismo], a fines del siglo XIX se empieza a hablar de poesía social. Víctor Hugo, etc. ¿La poesía puede expresar [un] programa político? Ningún programa sirve [para hacer] poesía. La poesía como programa no vale. Puede valer como testamento. La poesía tiene que ser pura y libre; no puede presometerse a ideas" (Jiménez, 1999, p. 72; el énfasis es mío). A pesar de ello, sí hay poemas políticos entre los poetas modernistas. De Rubén Darío basta con citar "A Roosevelt".
} 
se fuga de la realidad para fascinarse con el cielo creado por él mismo y disfrutar, lejos del mundanal ruido, su grandeza desde su "torre de marfil", así:

se constata un momento cultural enormemente paradójico; por un lado, se corrobra, reconoce y exalta la originalidad, novedad aristocracia, elegancia y selección minuciosa como atributos de un estilo; por otra, casi en sentido inverso, tácitamente, se aspira al reconocimiento, la fama pública y la amplia divulgación (Díaz Ruiz, 2007, p. 60).

Dicho lo anterior, se podría considerar que el modernismo, por sus mismos afanes artísticos, no se preocupó necesariamente de las problemáticas sociales y no coadyuvó a denunciar o mejorar las condiciones de desigualdad e injusticias en las poblaciones más desventajadas. Por ejemplo, para el caso mexicano, se dieron pocas expresiones que contemplaran las voces de los sectores vulnerables que sufrieron a causa de la dictadura de Porfirio Díaz, pues muchos de los poetas participaron activamente en el gobierno y la diplomacia.

De este modo, se puede decir poco del modernismo desde la óptica de la justicia social o distributiva, pero quizás desde el punto de vista de la justica como abstracción, como expresión del deber ser o prístina sensación, los poetas modernistas tengan mucho qué decir. Ya que incluso en esa república de las letras, idealizada y abstraída de las demandas populares, existía un pedestal para la justicia.

\section{La justicia en el modernismo mexicano}

En México, como en los demás países latinoamericanos, el modernismo tuvo peculiaridades. Es lugar común afirmar que el romanticismo se funde con el temperamento modernista y que la mayoría de nuestros poetas participan de ambas escuelas.

En los poetas "modernistas" vino a encontrar el romanticismo su expansión y resarcimiento; en entonces ya ningún rigor lo cohibió. Fueron los poetas "modernistas" quienes ya libremente hicieron popular en el paisaje cadencias embriagadoras y brillos miliunanochescos; no hubo objeto, por inerte que fuera, que al caer en su radio de atención no se prestara a complacer sus sentimientos y a obscurecer su propia realidad (Cuesta, 1994, p. 312).

Dentro de estos objetos se puede pensar en una estatua: la figura de la justicia, que ya sea como Themis o Justitia se alza como una mujer fatal de balanza y espada. Este objeto inerte, siguiendo la cita de Jorge Cuesta, se presenta invariablemente en el imaginario del escritor decimonónico. El letrado, personaje que domina el arte de la palabra, ya sea desde la literatura, el periodismo y la abogacía, también intenta describir una de las preocupaciones más profundas en la historia de la humanidad: las cualidades de lo justo. A partir de esta idea, dos de los poetas más celebrados del modernismo, Salvador Díaz Mirón ${ }^{5}$ y Manuel Gutiérrez Nájera ${ }^{6}$, consagran por lo menos un poema a la justicia. Los poemas son "Justicia”, de Salvador Díaz Mirón, y "Justicia seca”, de Manuel Gutiérrez Nájera.

\footnotetext{
${ }^{5}$ José Santos Chocano describe del siguiente modo los rasgos políticos de Salvador Díaz Mirón: "El poder hipnótico de Díaz Mirón lo domina; la fiebre, al fin, es una enfermedad contagiosa [...] Díaz Mirón nunca camina inclinado, porque no es de aquellos que llevan llagas en las rodillas a fuerza de doblegarlas. Liberal de la escuela moderna, sacrifica lo individual a lo humanitario; el pueblo soberano es su ideal, y, por eso, apostrofa a Napoleón Emperador, respetando a Bonaparte General” (Díaz Ruiz, 2007, p. 69).

${ }^{6}$ Rufino Blanco Fombona anota sobre el sentimentalismo del poeta: "Gutiérrez Nájera no obedece, en verdad, sino a su propio ser, y por eso, porque fue sentimental, siempre permaneció sentimental el fondo de su poesía. Hombre capaz de impresionarse por cosas de varia índole, y aun índole antitética que no en balde poseía extraordinaria sensibilidad, fue capaz de reflejar emociones distintas en su arte” (Díaz Ruiz, 2007, p. 187).
} 
Una de las cuestiones que unen a los poemas más allá de la temática (que será desarrollada de forma distinta por cada uno de ellos), es que ambas composiciones pertenecen a una etapa de juventud o de primera obra. El poema de Manuel Gutiérrez Nájera está fechado alrededor en 1880 y el de Salvador Díaz Mirón se publica, de acuerdo con la edición crítica de Manuel Sol, el 15 de abril de 1886 en El Parnaso Mexicano. En esta etapa, la justicia, junto con otros temas notables como el amor, la naturaleza, la religión, etc., se muestran de forma inmediata y prematura entre las preocupaciones de los jóvenes poetas. En el contexto mexicano, después de sufrir guerras sangrientas y restaurarse la República, la pax porfiriana propiciaba en el ámbito institucional la formalidad jurídica y política, que mucho contribuyó al marco de una política liberal clásica, escenario que finalmente zanjó los intereses del Estado y la Iglesia. Existían, por ello, motivos para hablar de justicia. Otro punto de contacto entre los dos poemas es que aún poseen un fuerte sedimento romántico. No se muestran aún los lances métricos, melódicos y léxicos del modernismo ni la simbiosis entre ciencia y arte en una subjetividad secular.

\subsection{La justicia según Gutiérrez Nájera}

El poema "Justicia seca”, de Manuel Gutiérrez Nájera, anterior en fecha al de Díaz Mirón, busca enlazar el tópico universal del desamor con los procedimientos de la justicia. El poeta apela no a una justicia tutelar, sino a una justicia diáfana que se presenta con el infalible paso del tiempo. La pieza, construida en coplas manriqueńas, se puede sintetizar en un verso de la primera estrofa: "sólo el tiempo bien castiga". Éste, advierte el poeta, actúa como un "inflexible vengador". El tiempo, entonces, no actúa desde los canales ordinarios. En vez de actuar como juez, se presenta en la vida de las personas como vengador. Podría decirse que el tiempo es justiciero del corazón: su objetivo, más que resarcir el daño, es punitivo.

Pero para que exista justicia, primero es preciso que sobrevenga un litigio. Así en la segunda estrofa se dice "En los conflictos de amores / mal nos aconseja, herida, / la altivez; / de corazones traidores, / la vida y no más la vida / es el juez” (Gutiérrez Nájera, 1953, p. 241). Mientras que el tiempo actúa como vengador de los corazones rotos, la vida, en un devenir de experiencias y sucesos, procede como juez. La vida hace que el sujeto obtenga templanza con el paso de los años: no hay que ser presa de las emociones y el rencor, pues al final el tiempo colocará a cada quien en su sitio. "Si te engaña la que quieres / o te abandona inconstante, / ya verás / cómo, sin que mucho esperes, / se burla de ella otro amante / mucho más" (pp. 241-242).

Pero el cenit del léxico jurídico se da cuando el poeta metaforiza el problema con conceptos penales: "Juzga el tiempo inexorable/ estos delitos de leso / corazón, / y aplica siempre al culpable / la dura ley sin proceso / del Talión" (Gutiérrez Nájera, 1953, pp. 242). Para el sentimentalismo exacerbado de Gutiérrez Nájera, a la par de los delitos de lesa majestad o lesa humanidad, subsisten conductas de "lesa sentimentalidad" ". Las relaciones entre la justicia y el amor no se encuentran desvinculadas, todo lo contrario, se ligan en su poder emotivo (Ricoeur, 2009, pp. 15-45). Pero quizás lo más elocuente es que al culpable se le retiran todas sus garantías: sufrirá una "dura ley sin proceso" que es precisamente la Ley del Talión, medida de reciprocidad, donde al agresor se le impone un castigo en la misma proporción que la falta cometida. El poeta alaba la justicia retributiva, que es de las formas más ancestrales de hacer

\footnotetext{
${ }^{7}$ Sobre la unión entre justicia y sentimiento, Alejandro Nieto apunta sobre el sentimiento de justicia: "Yo creo en la Justicia, mas no como idea abstracta y mucho menos intertemporal, sino como sentimiento, que es una realidad verificable en cuanto que yo y casi todos los seres humanos percibimos nuestros propios sentimientos de justicia, compartidos o no por los demás hombres. De la misma manera que no creo en la Belleza abstracta, permanente ahistórica y universal; pero sí en el sentimiento individual de belleza que cada individuo tiene en un momento determinado y ante un objeto preciso" (Nieto, 2002, p. 268; el énfasis es mío).
} 
justicia y solucionar conflictos. Al final el poeta invita al lector a confiar en la balanza de esa "Justicia seca": "Y si es tan fiel su balanza, / si no perdona ni olvida / lo que fue, / ¿para qué tomar venganza / ni esperarla en otra vida? / ¿Para qué?” (Gutiérrez Nájera, 1953, p. 242).

\subsection{La justicia según Díaz Mirón}

Mientras que Gutiérrez Nájera emplea el lenguaje de la justicia para explicar los conflictos amorosos, Salvador Díaz Mirón apela a un sentido de justicia más ontológica, a una moral que contrasta con las creencias de la burguesía liberal que únicamente miran el delito en el derecho y no en otras fuentes normativas. Es precisamente en la moral deontológica, como normatividad universal, donde Salvador Díaz Mirón mira que todos los hombres son, en cierta medida, pecadores y trasgresores del orden. Esta situación lo llevará, antes de consagrarse el derecho social con la Constitución de 1917, a preocuparse por las clases oprimidas y defender los derechos humanos ${ }^{8}$. También estas preocupaciones de justicia social se verán en el poema "Asonancias" publicado el 4 de enero de 1886 en El Valedor. En este sentido, la poesía "comprometida" de Salvador Díaz Mirón lucha en contracorriente con la visión hegemónica que después enarbolará el modernismo. Las cuestiones sociales son parte no sólo de su agenda poética, sino política. La labor como congresista ${ }^{10}$ es también vital en su trayecto intelectual.

El poema "Justicia" inicia con un epígrafe anónimo: "Fuerza es convenir en ello: / todo hombre es un pecador; / no hay nadie que en su interior / no esté con la soga en el cuello" (Díaz Mirón, 1997, p. 330). Aquí se encierra la tesis moral: todo hombre invariablemente está condenado por las fuerzas que lo superan. Así, la voz del poema es un prisionero condenado a la horca. Habla para sí, pues le es imposible arrojar su pensamiento. "Pero, altivo en mi tormento, / miro el tiempo que pasó... / ¡Que las faltas en que yo / frágil como hombre, incurrí, / podrán afligirme, sí; / pero avergonzarme, no!" (p. 330). El condenado no se arrepiente y se encuentra

${ }^{8}$ En la introducción a la Poesía completa del poeta, hecha por Manuel Sol, existe un apartado que se titula "Defensor de los derechos humanos", donde se narra el seguimiento que Salvador Díaz Mirón, como periodista, hizo al caso del fusilamiento masivo que el gobernador de Veracruz, el general Luis Mier y Terán, ordenó en la noche del 24 de junio de 1879. Los fusilados eran nueve personas acusadas de conspiración a favor de don Sebastián Lerdo de Tejada. Los artículos del Diario Comercial, que criticaban fuertemente el gobierno local, terminaron en el emplazamiento de un duelo: "Por consiguiente, cuando Díaz Mirón firmó un artículo con su nombre en uno de los periódicos de mayor circulación en el estado, la dignidad de Mier y Terán se sintió humillada más que nunca y su primera reacción fue la de retar al poeta, del que seguramente ya lo distanciaban algunas diferencias" (Díaz Mirón, 1997, p. 43). El duelo no se llevó a cabo y el problema se turnó a una comisión especial. Este episodio remarca dos pasiones del poeta, por un lado, la afición a los duelos (recordemos que el poeta estima en alto las disputas de honor a tal grado que se batió en duelo con diversos personajes y perdió la movilidad del brazo izquierdo) y su afinidad por acompañar las causas justas.

9 "Sabedlo, soberanos y vasallos, / próceres y mendigos: / nadie tendrá derecho a lo superfluo / mientras alguien carezca de lo estricto. / Lo que llamamos "Caridad", y ahora / es sólo un móvil íntimo, / será en un porvenir / lejano o próximo / el resultado del deber escrito. / Y la Equidad se sentará en el trono / de que huya el Egoísmo, / y a la ley del embudo, que hoy impera, / sucederá la ley del equilibrio” (Díaz Mirón, 1997,p. 329). Díaz Mirón apela a la fuerza legitimadora del derecho natural. Las acciones caritativas, que son gracias a la buena voluntad de los ricos, se convertirán eventualmente en un deber jurídico, legislado. En la alegoría se sentará la Equidad y el imperio de la ley será armoniosa.

${ }^{10}$ A propósito, Manuel Gutiérrez Nájera critica la actividad de Salvador Díaz Mirón como legislador. En el texto titulado "Poetas en la tribuna", publicado bajo el seudónimo de El Duque Job, en La Libertad el 16 de noviembre de 1884, dice: "El tribuno que esta discusión ha revelado es Salvador Díaz Mirón. No presentó ningún argumento sólido contra el arreglo de la deuda, pero sí tuvo rasgos oratorios muy felices, y habló con elegancia y entusiasmo. Yo deploro oír hablar a Díaz Mirón en el Congreso. La poesía es un barco que se incendia: todos los poetas se arrojan al agua o lo que es lo mismo a la política” (Gutiérrez Nájera, 1995, p. 68). 
completamente consciente de lo que hizo. No hay vergüenza porque las acciones delictivas se cometieron en un contexto justificatorio que no se identifica con los valores del derecho positivo.

Al final, la humanidad es víctima y victimaria en su plenitud, nadie se escapa a ese juicio universal: "¡Dicen que todo mortal, / hasta el que lleva una palma, / es, por el fallo de su alma, / un condenado al dogal!" (Díaz Mirón, 1997, p. 330). Ante el fallo del alma, inapelable y perpetuo, todos los seres humanos (incluso aquellos sobresalientes y virtuosos) son imperfectos. Por lo tanto, están condenados al dogal. A pesar de ello, la justicia terrenal, aquella que funciona con las instituciones y reglas de los hombres, genera las desigualdades que esa justicia espiritual ${ }^{11}$ consagra. "Mas no tienen suerte igual / la púrpura y el andrajo: / cuando el culpable no es bajo, / es menos vil su sentencia... / Por eso yo en mi conciencia / ¡reclamo el hacha y el tajo!” (Díaz Mirón, 1997, p. 330). Las leyes humanas, pervertidas y tergiversadoras, no tratan igual al pobre y al rico. La sentencia está en función de las clases sociales y la "honorabilidad" del reo. El prisionero, tomando las leyes innatas de su conciencia como sistema normativo, demanda otra justicia que invierte los papeles. Él, amparado por las atrocidades, ejecuta a su verdugo.

\section{Compasión y virtud en el acto de juzgar}

Después de la elaboración de estos poemas iniciales ("Justicia seca” y "Justicia”), donde ambos escritores representan a su modo una visión personal de la justicia, se puede escudriñar una evolución en torno a la aplicación de la misma: las características axiológicas y emocionales que supone la decisión justa son remarcadas por los poetas. Tanto Manuel Gutiérrez Nájera como Salvador Díaz Mirón atemperan con los años su perspectiva sobre el acto justo en sociedad. Los poetas se vuelven más reflexivos sobre la vida y, en sus textos de madurez, muestran una aproximación menos normativa y más integral sobre la justicia y lo que ésta debería perseguir: la paz. Si es cierto que otros autores miran la justicia como un fin último u observan otros fines pragmáticos como el bienestar, o prestan atención a fines espirituales y morales como la felicidad y el desarrollo integral del ser humano ${ }^{12}$; para estos poetas modernistas, quizás debido al contexto belicoso del siglo XIX mexicano, el fin supremo se traduce en un ánimo pacificador. Restituir el tejido social (usando una metáfora cientificista) de una sociedad que ha quedado deshecha por la guerra y la venganza.

En el poema "Pax Animae", de Manuel Gutiérrez Nájera, fechado aproximadamente en $1890^{13}$, el autor "después de leer a dos poemas" (como aparece en el subtítulo del poema),

\footnotetext{
${ }^{11}$ A partir de los sentidos originales de justicia, Luis Villoro apunta: "Justica, en suma, se aplica al orden de un todo y las reglas necesarias que deben regir para que un conjunto sea efectivamente un todo regulado, Este sentido de justicia dará lugar, más tarde, al concepto de ley natural de Aristóteles y de los estoicos como medida del orden moral y a la noción de normas universales de justicia. Injusto es lo que no cumple esa ley, lo que se sale del orden por transgredir la norma universal" (2007, p. 43).

${ }^{12}$ Luis Villoro describe un modelo teleológico (conforme al fin) y un modelo deontológico (conforme al deber) para explicar los sentidos de la justicia. Estos dos modelos, de acuerdo a su teoría, se contraponen entre sí. Dentro del primero, distingue a la justicia como virtud y a la justicia como ley. En un sentido amplio, la justicia "no se trata de descifrarla al través de las reglas y principios sociales aprendidos, sino de aprehenderla en el trato personal con los demás en sociedad. Comprendamos que la justicia se encuentra en una forma de estar ligados con los otros en un todo social. Antes de analizarla, percibimos la justicia como un valor concreto que nos concierne al vivir bien nuestra vida en sociedad y que deseamos que rija también a los demás" (2007, p. 60).

${ }^{13}$ Recordemos que antes de llegar a este poema, desde el periodismo Manuel Gutiérrez Nájera reflexiona sobre los temas de la libertad y el derecho. Sobre la libertad de imprenta, el poeta mantiene una opinión reservada sobre los abusos de este derecho. En el artículo "Libertad, no libertinaje", publicado en El Nacional el 25 de octubre de 1881, dice: "Que haya, sí, libertad plenísima, absoluta, de emitir toda estirpe de opiniones; que la verdad pueda combatir en campo abierto con el absurdo; que lidien todas las ideas y todos los sistemas: no queremos
} 
inicia con el siguiente exhorto: “Ni una palabra de dolor blasfemo! / Sé altivo, sé gallardo en la caída, / ¡y ve, poeta, con desdén supremo / todas las injusticias de la vida!” (Gutiérrez Nájera, 1953, p. 223). El poeta, conocedor de la belleza última y las sensaciones más sublimes, no debe detenerse en "la constancia de los amores", pues éstos siempre son fugaces y volátiles. Los seres humanos, recuerda el poeta, no pueden aspirar a estados eternos ni inmutables, por eso recomienda hacer monumentos sepulcrales con los dolores: labrar estatuas con las palabras. De lo que surge el interrogante : “A qué pedir justicia ni clemencia / si las niegan los propios compañeros / a la glacial y muda indiferencia / de los desconocidos venideros?” (p. 224).

Los recuerdos buenos son como pequeńos ramilletes que hay que guardar con aprecio en la memoria. La ética del poeta, fundida con la estética, hace de la nostalgia un eje de vida verdadera, siguiendo quizás la tradición clásica de Jorge Manrique que establece "cualquier tiempo pasado fue mejor". Alzar la vista, mirar el cielo y reconocer el azul que entusiasmó a toda una generación de poetas: "En esta vida el único consuelo / es acordarse de las horas bellas, / y alzar los ojos para ver el cielo... / cuando el cielo está azul o tiene estrellas" (p. 224). Al reflexionar sobre estos recuerdos, toda afrenta puede ser subsanada. El mal no es mayor que la belleza ${ }^{14}$. "AAy! Es verdad que en el honrado pecho / pide venganza la reciente herida... / pero... ¡perdona el mal que te hayan hecho! / ¡Todos están enfermos de la vida!” (p. 224). Se trata de una reformulación de la ética cristiana de "dar la otra mejilla", de ejercer la virtud cardinal de la templanza en código escolástico. Aunque el corazón pide venganza, la razón como recta vía disuade al sujeto para desquitarse de su agresor. Pero el aporte ético del poema no radica sólo en esta reconsideración moral, pues si las subjetividades están "enfermas de vida", entendiéndose como el determinismo social que la sociedad, el Estado y la religión ejercen sobre las personas, el juzgador queda trastocado en su autoridad: “¿Eres acaso el juez? / ¿El impecable? / ¿Tú la justicia y la piedad reúnes? / ¿Quién no es fugitivo responsable / de alguno o muchos crímenes impunes?" (p. 225).

El poeta pregunta, como pidiendo que se lance la primera piedra: “¿Quién no ha mentido amor y profanado / de una alma virgen el sagrario augusto? / ¿Quién está cierto de no haber matado? / ¿Quién puede ser el justiciero, el justo?” (p. 225). El ser humano, sin excepción, ha obrado en algún momento de forma contraria a la moral y al derecho. Las personas invariablemente han quebrantado algún mandamiento moral o han violado alguna disposición jurídica. Por esta razón, el justiciero y el justo se encuentran débilmente separados por una línea que a veces no se distingue. Ante esto, hay que ejercer el perdón y la compasión al reconocer que el lugar del infractor puede ser ocupado por cualquier otra persona "buena”. “iLástima y perdón para los vivos! / Y así, de amor y mansedumbre llenos, / seremos carińosos, compasivos... /

una democracia asustadiza ni medrosa, sino una democracia tranquila, altiva, confiada en sus propias fuerzas y en su propia bondad, pero que se proscriban para siempre esos cobardes y rastreros desahogos de las nulidades ofendidas, esas diatribas de taberna" (Gutiérrez, 1995, p. 46). Asimismo, critica el espíritu de la Constitución de 1857 y su materialización en La Colonia Española del 5 de febrero de 1879: "Tenemos una Constitución que sanciona los derechos individuales, y los derechos individuales nos son absolutamente desconocidos. ¡Qué ha de saber de derechos individuales el que sólo ve 'la leva' y los impuestos! Necesitábase robustecer al Estado para evitar así gravísimos conflictos, y la Constitución da entrada franca a todo género de rebeliones [...]. Hoy el pueblo no quiere ya palabras, sino garantías. No garantías abstractas y ficticias como las que ahora tiene, sino garantías sólidas y verdaderas. Más que libertad escrita quiere orden establecido" (1995, p. 135).

${ }^{14}$ Para Rogelio Guedea, "La influencia de la literatura francesa en Gutiérrez Nájera es obvia y es, a su vez, un alejamiento del color local, sin dejar de pintar una parte también de lo mexicano: la alta cultura. Pero como lo hace con gracia, y casi con ironía, sigue siendo Nájera un afrancesado mexicanista [...]. Obviamente, Nájera es exquisito pero cede a la tristeza, al sentimentalismo. Bajo la tutela de Hegel en cuanto a su concepción de la belleza, Gutiérrez Nájera atisba un modernismo romantizado" (2011, pp. 86-87). 
iy alguna vez, acaso, acaso buenos!" (p. 225) ${ }^{15}$. El poeta establece en el poema varias acciones fundamentales para lograr la vida pacífica. La prudencia, también como una virtud cardinal, debe ser ejercida diariamente en el camino hacia el Areté. "Recordar... perdonar... Haber amado... / Ser dichoso un instante, haber creído... / Y luego... reclinarse fatigado / en el hombro de nieve del olvido" (p. 226). El poeta aconseja a su lector cortar las rosas en el jardín, sabiendo que invariablemente hay que perdonar las espinas: "Ama y perdona. Con valor resiste / lo injusto, lo villano, lo cobarde... / ¡Hermosamente pensativa y triste / está al caer la silenciosa tarde" (p. 227).

Por su parte, Salvador Díaz Mirón, en un poema que no se encuentra fechado, pero que se presume de su segunda etapa creativa (1892-1901) por el estilo y la temática, expone el sentido de la vida cuando ésta se ha extinguido. En "Requiescat in pace", la voz lírica se coloca ante el escenario del fallecimiento de un hombre virtuoso. Díaz Mirón, desde la primera estrofa, celebra y aplaude la muerte. No hay motivos para llorar en el sepelio de un buen hombre, pues " ¡Ś́, que en esta cruel guerra / el justo anhelará de polo a polo / dormir bajo la tierra, / ya que sobre ella sólo / reina la fuerza y predomina el dolo!” (Díaz Mirón, 1997, p. 377).

El mundo, lugar donde la brutalidad y la injusticia imperan, no es sitio para el probo. El justo busca el sueño eterno y fugarse de la vida cruel que lo somete a fuerzas intratables. En la tierra, siguiendo la descripción del poeta, se dará el imperio de la ley humana, es decir, el poder y el yugo. Predomina además el dolo, ya sea desde un sentido jurídico o moral, la mala fe que ocasiona fraudes y crímenes. En la vida, lo esencial es la congruencia entre nuestras palabras y acciones. Los asesinos deben reconocerse como tales. "No vertáis ¡oh perversos! / de irrisorio dolor estéril jugo. / ¿No ayer fuisteis adversos / al vivo, cual os plugo? ¿Plañe acaso a la víctima el verdugo?” (p. 378) ${ }^{16}$.

Por esta razón, el justo trasciende los honores. Los reconocimientos y títulos no son importantes para quien sabe que su acciones van más allá de las instituciones humanas. De algún modo, al igual que el carácter asceta, el espíritu virtuoso se aleja de las fiestas, de los elogios y emolumentos: " $\mathrm{OOh}$ tímido y profundo / espíritu, que siempre huiste el ruido / y la pompa del mundo! / ¡Logres lo que has querido: / no eterna fama, sino eterno olvido” (Díaz Mirón, 1997, p. 378).

La Fama, como diosa romana, extendía los rumores y las hazañas de los hombres, sin importar que estos fueran ciertos o falso, sin saber si eran justos o no. Al espíritu, sugiere Díaz Mirón, no le inquieta el sonido de la trompeta de esta deidad, pues los verdaderos aplausos se dan en el interior. Al final los valores se alternan. “ $\mathrm{iA}$ ti fuera desdoro / lo que es presea en

\footnotetext{
${ }^{15}$ Una de las teorías más interesantes sobre este asunto, es la justicia como cuidado existencial de Norbert Bilbeny: "La justicia como cuidado existencial es una justicia compasiva. Pero esto no significa identificar la justicia con la compasión ni que haya de ser sustituida por ésta. Porque la compasión sola, o el dejarse influir por ella, o un mal uso de ella, pueden anular la justicia o torcer su sentido racional, imparcial e imperativo [...]. No es justicia 'como' compasión, porque no se toma a este sentimiento como guía ni criterio evaluador de los actos y los veredictos justos. Ni menos es una justicia 'por' compasión, ya que ésta es descartada como fundamento o razón de ser de la justicia, que oscilaría al albur de un sentimiento [...]. Justicia, en cambio, «con» compasión, no latera la identidad de lo que es proceder de modo justo, porque el sentimiento no determina este proceder ni tampoco está obligado a acompañarlo. La compasión se tiene o no se tiene, pero lo humano es tenerla y es bueno humanamente que se tenga. Difícilmente la justicia escapará de esta realidad y a la vez de este deseo" (2015, p. 202).

${ }^{16}$ A propósito de la discusión sobre la moralidad de Salvador Díaz Mirón, donde Genaro Fernández Mac Gregor lo define como un ser antisocial, Jorge Cuesta llega a la siguiente reflexión criminológica: "lo mismo los sanos que los enfermos reaccionan con hostilidad en contra de lo que les causa un sufrimiento físico o moral. Pero el sufrimiento que la sociedad experimenta no es el mío. A lo mejor, mi crimen tiene en mí las consecuencias fisiológicas más saludables. Enfrente de ellas, no creo que podría admitir que mi crimen fuera mi enfermedad en vez de mi salud, sólo porque se demostrara que era un sufrimiento social” (1994, p. 215).
} 
nuestros circos fieros; / lo que obtienen del coro, / triunfantes y altaneros, / los más audaces y los más arteros!" (p. 378).

Además de que el virtuoso ejerce la justicia, también es preciso que tenga a la piedad como divisa. Este espíritu logra la sabiduría cuando encuentra paz a la sombra del follaje de los árboles: en la lobreguez natural. "¡Sabio quien busque y halle / a la sombra del árbol paz cumplida / en apartado valle, / cabe limpia y dormida / corriente, imagen de su propia vida!" (Díaz Mirón, 1997, p. 379) ${ }^{17}$. Finalmente, el poeta veracruzano alienta al lector a buscar la virtud en la tierra misma. "No cultivéis ¡oh buenos! / más tierra que la tierra. El barro humano / vale a vosotros menos / que el que nutre al gusano / y da una planta a quien le arroja un grano" (p. 379).

\section{Conclusión: Justicia, ética y poesía}

Los dos tratamientos que articulan por separado los poetas, responden a un ideal diferente de justicia. Para Gutiérrez Nájera, el tópico de la justicia es usado para explicar a partir de lenguaje formalista los idilios y "litigios amorosos" que un sujeto puede sufrir con el ser amado. En este sentido, el poeta apela a una justicia transparente, que ocurre gracias al paso del tiempo, implícita y paciente. Los conceptos jurídicos y morales son ocupados principalmente para metaforizar el problema cualitativo del desamor. Por su parte, Salvador Díaz Mirón, quien utiliza la poesía para visibilizar problemáticas de la impartición real de la justicia, lleva a un nuevo nivel la alianza entre derecho y poesía. Existe una justicia identificada con el derecho natural que poseen los hombres para ser tratados dignamente. Esta justicia no puede ni debe soslayarse. Incluso, extrapolando los fines trascendentales de esta normatividad axiológica, todos los individuos comenten injusticias en algún momento de su vida. Así, nadie está legitimado para condenar a sus pares. El poeta remarca el aspecto material, de contenido, sobre las formalidades dadas por los procedimientos de una ley convencional. Al final la moral es más digna y fuerte que cualquier sistema jurídico.

En la madurez, ambos poetas sujetan el tema de la justicia en el terreno de la ética, donde es preciso relacionarla con la virtud. La concepción de lo justo se vuelve integral y en función de la trayectoria vital del sujeto. Mientras que para Manuel Gutiérrez Nájera la paz es la finalidad de las acciones justas, donde la empatía y la compasión suponen rasgos insoslayables para quien emite un juicio; para Salvador Díaz Mirón, la justicia más auténtica se adquiere a través de un ejercicio de virtuosismo y de trascendentalismo ético. El plano espiritual es inverso a los bienes terrenales, la competencia y la fama.

\section{Referencias bibliográficas}

Bilbeny, N. (2015). Justicia compasiva. Madrid: Tecnos.

Cuesta, J. (1994). El clasicismo mexicano; Salvador Díaz Mirón. En J. Cuesta. Obras. México: Ediciones del Equilibrista, ts. I-II.

\footnotetext{
${ }^{17}$ El tránsito ético de la vida de Díaz Mirón puede observarse desde su poesía, que va desde la extravagancia a la serenidad y silencio. Como señala Cuesta: "Los desfallecimientos de la poesía de Díaz Mirón adquieren otro color en cuanto se miran con los ojos que entraron en la intimidad de una estética que parece una insensibilidad, sólo por lo gratuita que es su tortura. La distancia entre la banalidad de sus asuntos y la rareza de la gloria que de ellos extrae, se puebla de angustias que no podrían caber sino en una gran serenidad, que debe estar muy lejos de ser una insensibilidad, una ausencia de sentimientos y que significa el silencio que guardó Díaz Mirón durante los numerosos y largos años que sucedieron a la publicación de Lascas" (1994, p. 215).
} 
Díaz Mirón, S. (1997). Poesía completa. Manuel Sol (ed.). México: FCE.

Díaz Ruiz, I. (comp.) (2007). El modernismo hispanoamericano: testimonios de una generación. México: CIALC-UNAM.

Guedea, R. (2011) Reloj de pulso. Crónica de la poesía mexicana de los siglos XIX y XX. México: UNAM.

Gutiérrez Nájera, M. (1953). Poesías completas. Francisco González Guerrero (ed. y pról.). México: Porrúa, ts. I-II.

Gutiérrez Nájera, M. (1995). Mañana de otro modo. México: IIF-UNAM.

Jiménez, J. R. (1999). El modernismo. Apuntes de curso (1953). Madrid: Consejería de Educación y Cultura/Visor.

Nieto, A. (2002). Balada de la justicia y la ley. Madrid: Trotta.

Paz, O. (1997). Los hijos del Limo. En O. Paz. La casa de la presencia. Poesía e historia. Obras completas. México: FCE.

Ricoeur, P. (2009). Amor y justicia. Trad. Adolfo Castañón. México: Siglo XXI.

Villoro, L. (2007). Los retos de la sociedad por venir. Ensayos sobre justicia, democracia y multiculturalismo. México: FCE. 